\title{
Annular Erythema of Infancy With Reactive Helper T Lymphocytes
}

\author{
Patrick Tran, MD; Michael McLemore, MD
}

\section{PRACTICE POINTS}

- Annular erythemas of infancy (AEls) are rare benign skin eruptions characterized by persistent, annular, urticarial, nonpruritic patches and plaques that develop in patients younger than 1 year.

- Although AEls are benign, lesions with uncommon histologic features such as large mononuclear cells consistent with reactive helper $\mathrm{T}$ lymphocytes may pose diagnostic challenges.

Annular erythemas of infancy (AEls) are rare benign skin eruptions characterized by persistent, annular, urticarial, nonpruritic patches and plaques that develop in patients younger than 1 year. Histologically, a skin biopsy typically demonstrates a perivascular infiltrate in the dermis composed of small lymphocytes, neutrophils, and increased scattered eosinophils. We report a case of an AEI in an 11-month-old girl with uncommon histologic features. Recognition of these benign cells is important to avoid misdiagnosing them as atypical or neoplastic. We also provide a review of the differential diagnosis for AEls.

Cutis. 2021;108:289-291.

A nnular erythemas of infancy (AEIs) are rare benign skin eruptions characterized by annular or circinate, erythematous patches and plaques that arise in patients younger than 1 year. ${ }^{1}$ Annular erythemas of infancy originally were described by Peterson and Jarratt ${ }^{2}$ in 1981. Relatively few cases of AEIs have been reported in the literature (eTable). ${ }^{2-15}$

\section{Case Report}

An 11-month-old girl presented to dermatology for a rash characterized by annular erythematous patches and plaques on the back, arms, and legs (Figure 1). Three months prior, the rash was more diffuse, monomorphic, and papular. Based on physical examination, the differential diagnosis included a gyrate erythema such as erythema annulare centrifugum (EAC), neonatal lupus, a viral exanthem, leukemia cutis, and AEI. A skin punch biopsy was performed.
Histologically, the biopsy revealed a superficial to mid dermal, tight, coat sleeve-like, perivascular lymphohistiocytic infiltrate admixed with rare neutrophils in eosinophils within the dermis (Figure 2A). The infiltrate also contained numerous large mononuclear cells with enlarged nuclei, fine loose chromatin, rare nucleoli, and a thin rim of cytoplasm (Figure 2B). There were associated apoptotic bodies with karyorrhectic debris. Immunohistochemistry exhibited enlarged cells that were strong staining with CD3 and CD4, which was consistent with reactive helper T cells (Figure 3). A myeloperoxidase stain highlighted few neutrophils. Stains for terminal deoxynucleotidyl transferase, CD1a, CD117, and CD34 were negative. These findings along with the clinical presentation yielded a diagnosis of AEI with reactive helper T cells.

\section{Comment}

Clinical Presentation of AEIs - Annular erythemas of infancy are rare benign skin eruptions that develop in the first few months of life. ${ }^{1,16}$ Few cases have been reported (eTable). Clinically, AEIs are characterized by annular or circinate, erythematous patches and plaques. They can occur on the face, trunk, and extremities, and they completely resolve by 1 year of age in most cases. One case was reported to persist in a patient from birth until 15 years of age. ${ }^{9}$ It is thought that AEIs may occur as a hypersensitivity reaction to an unrecognized antigen.

Histopathology-Histologically, AEIs demonstrate a superficial and deep, perivascular, inflammatory infiltrate in the dermis composed of small lymphocytes, some neutrophils, and eosinophils. ${ }^{16}$ Less common variants of AEI include eosinophilic annular erythema, characterized by a diffuse dermal infiltrate of eosinophils and some lymphocytes, and neutrophilic figurate erythema of infancy, characterized by a dermal infiltrate with neutrophils and leukocytoclasis without vasculitis. ${ }^{1}$

Our patient's skin rash was unusual in that the biopsy demonstrated few neutrophils, rare eosinophils, and larger mononuclear cells consistent with reactive helper

From the University of California, Los Angeles, David Geffen School of Medicine.

The authors report no conflict of interest.

The eTable is available in the Appendix online at www.mdedge.com/dermatology.

Correspondence: Patrick Tran, MD, 1000 W Carson St, Torrance, CA 90502 (ptran4@dhs.lacounty.gov).

doi:10.12788/cutis.0387 
FIGURE 1. A, An 11-month-old girl with annular erythematous patches and plaques on the back. B, Annular erythematous lesions were present on the right arm, from which a punch biopsy was taken.

FIGURE 2. Histopathology demonstrated annular erythema of infancy with mononuclear cells. A, There was a superficial to mid dermal, tight, coat sleeve-like, perivascular, lymphohistiocytic infiltrate admixed with rare neutrophils in eosinophils within the dermis ( $\mathrm{H} \& \mathrm{E}$, original magnification $\times 40$ ). $B$, The infiltrate contained numerous large mononuclear cells with enlarged nuclei, fine loose chromatin, rare nucleoli, and a thin rim of cytoplasm (H\&E, original magnification $\times 400$ ).

FIGURE 3. A, Immunohistochemistry revealed the infiltrate was composed predominantly of $\mathrm{CD}^{+} \mathrm{T}$ lymphocytes (original magnification $\times 100$ ). $\mathrm{B}$, The enlarged cells were $\mathrm{CD}^{+}{ }^{+}$, consistent with reactive helper $\mathrm{T}$ cells (original magnification $\times 400$ ).
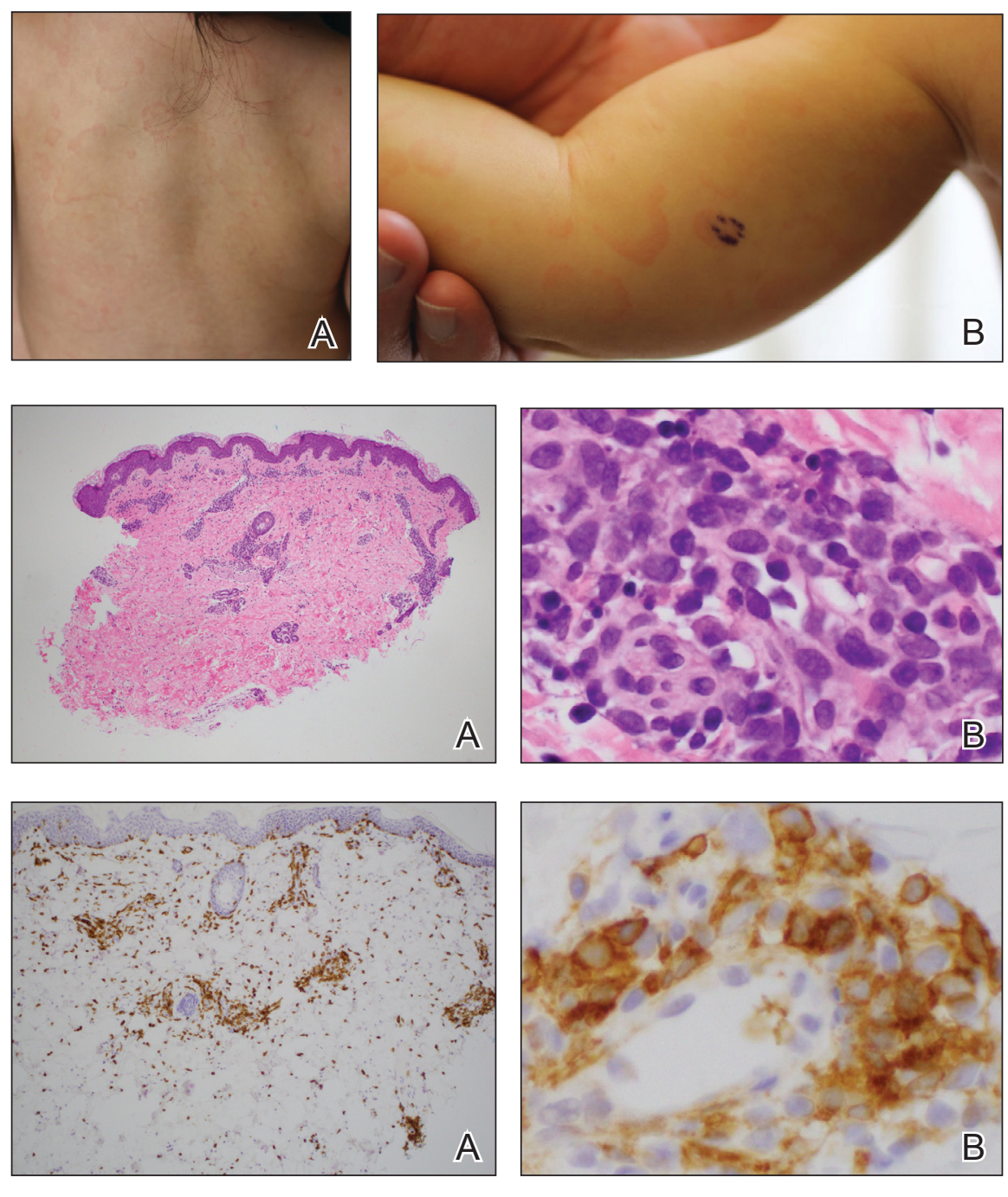

$\mathrm{T}$ lymphocytes. Although these cells may raise concern for an atypical lymphoid infiltrate, recognition of areas with more conventional histopathology of AEIs can facilitate the correct diagnosis.

Differential Diagnosis-The main considerations in the differential diagnosis for AEIs include the following: EAC, familial annular erythema, erythema gyratum atrophicans transiens neonatale, erythema chronicum migrans, urticaria, tinea corporis, neonatal lupus erythematosus, viral exanthems, and leukemia cutis. ${ }^{16}$

Erythema annulare centrifugum typically begins in middle age and follows a course of 2 or more years. ${ }^{2}$ It occurs in association with an underlying infection or neoplasm, and it can develop on the trunk and proximal extremities. Morphologically, EAC can present with arcuate or polycyclic lesions with trailing scale. Histologically, a skin biopsy shows a tight, coat sleeve-like, perivascular, lymphohistiocytic infiltrate in the dermis, with variable epidermal spongiosis and parakeratosis. ${ }^{16}$ Our patient's biopsy did show a tight perivascular infiltrate, raising suspicion for EAC. However, the eruption occurred in infancy, and she had no clinical evidence of infection or neoplasm.
Familial annular erythemas can arise within a few days after birth and can present on any part of the body, including the tongue. ${ }^{2}$ Individual lesions can persist for 4 to 5 days and can accompany congenital malformations. Morphologically, they can present as papules that slowly enlarge to form arcuate lesions with central hyperpigmentation. Histologically, there can be a mild, perivascular, lymphocytic infiltrate in the dermis. ${ }^{16}$ Our patient's lesions showed no scale or pigmentation and occurred without a family history or associated malformations.

Erythema gyratum atrophicans transiens neonatale also can arise in the first few days of life and can affect the trunk, neck, and lips. ${ }^{16}$ Morphologically, the skin lesions can present as arcuate erythematous patches (3-20 mm) with raised borders and central atrophy. Histologically, there is epidermal atrophy with a dermal perivascular mononuclear cell infiltrate with edema. Our patient's clinical presentation was not classic for this condition, and the lesions showed no atrophy.

Erythema chronicum migrans can arise in children, often with a history of an arthropod bite. ${ }^{13}$ Morphologically, lesions can evolve over weeks to months and rarely are multiple. 
Erythema chronicum migrans most commonly occurs in the United States in association with Lyme disease from infection with Borrelia burgdorferi. Histologically, erythema chronicum migrans shows a superficial and deep, perivascular lymphocytic infiltrate in the dermis with plasma cells and eosinophils. A silver stain can demonstrate dermal spirochetes. Our patient had no history of an arthropod bite. A Warthin-Starry stain performed on the biopsy was negative for spirochetes, and serologies for Lyme disease were negative.

Urticaria is rare in neonates and can occur on any part of the body. ${ }^{2}$ Morphologically, the skin lesions can present as arcuate, erythematous, and polycyclic plaques that wax and wane. Histologically, there is dermal edema with a mild, perivascular and interstitial, mixed inflammatory infiltrate. ${ }^{16}$ Our patient's biopsy did not reveal notable edema, and the perivascular infiltrate was coat sleeve-like with few neutrophils and eosinophils. The patient did not respond to initial treatment with antihistamines, making urticaria less likely.

Tinea corporis is rare in neonates and can occur on any part of the body. ${ }^{13}$ Morphologically, it can present as scaly annular lesions that are fixed and more persistent. Histologically, there are fungal hyphae and/or yeast in the stratum corneum with spongiotic dermatitis and parakeratosis. Our patient's lesions were not scaly, and the biopsy demonstrated minimal spongiosis. A periodic acid-Schiff special stain was negative for fungal microorganisms.

Neonatal lupus erythematosus can arise at birth or during the first few weeks of life. ${ }^{16}$ Morphologically, the skin lesions occur on the scalp, forehead, or neck in a periorbital or malar distribution. They can present as erythematous, annular, scaly patches and plaques. Transplacental transmission of material autoantibodies has been implicated in the etiology, and a complication is infantile heart block. Histologically, a skin biopsy typically shows interface/ lichenoid dermatitis. However, our patient's biopsy did not demonstrate interface changes, and serologically she was negative for autoantibodies.

Viral exanthems are skin eruptions that accompany underlying viral infections. ${ }^{17}$ Morphologically, patients can present with an erythematous maculopapular rash, sometimes with vesicular, petechial, and urticarial lesions. Laboratory confirmation is made by virus-specific serologies. Histologically, viral exanthems can show a superficial, perivascular, lymphocytic infiltrate in the dermis, with reactive $\mathrm{T}$ cells and epidermal spongiosis. Our patient was afebrile and had no known sick contacts. A cytomegalovirus immunohistochemical study on the biopsy was negative, and an Epstein-Barr encoding region in situ hybridization study was negative.

Leukemia cutis is the infiltration of the skin by leukemic cells, most often in conjunction with systemic leukemia. ${ }^{18}$ In infants and children, the most common leukemia is B-cell acute lymphoblastic leukemia. Morphologically, the skin lesions are characterized by single or multiple violaceous papules, nodules, and plaques. Histologically, there is a perivascular to interstitial infiltrate of atypical mononuclear cells in the dermis and sometimes subcutis. The leukemic cells demonstrate enlarged nuclei with coarse chromatin and prominent nucleoli. Increased mitotic activity may be seen with karyorrhectic debris. Immunohistochemically, the tumor cells can be positive for myeloperoxidase, CD43, CD68, CD34, and CD117. ${ }^{18}$ Although our patient's biopsy demonstrated mononuclear cells with karyorrhexis, the cells did not have striking atypia and were negative for blast markers. A recent complete blood cell count on the patient was normal.

\section{Conclusion}

We report an unusual case of AEI with mononuclear cells consistent with helper T cells. One must keep these cells in mind when evaluating a biopsy of AEI, as they are benign and not suggestive of an atypical lymphoid infiltrate or leukemia cutis. This will prevent misdiagnosis and ensure that the patient receives appropriate management.

\section{REFERENCES}

1. Ríos-Martín JJ, Ferrándiz-Pulido L, Moreno-Ramírez D. Approaches to the dermatopathologic diagnosis of figurate lesions [in Spanish]. Actas Dermosifiliogr. 2011;102:316-324. doi:10.1016/j.ad.2010.12.009

2. Peterson $\mathrm{AO}$, Jarratt M. Annular erythema of infancy. Arch Dermatol. 1981;117:145-148.

3. Toonstra J, de Wit RF. "Persistent" annular erythema of infancy. Arch Dermatol.1984;120:1069-1072.

4. Hebert AA, Esterly NB. Annular erythema of infancy. J Am Acad Dermatol. 1986;14:339-343.

5. Cox NH, McQueen A, Evans TJ, et al. An annular erythema of infancy. Arch Dermatol. 1987;123:510-513.

6. Helm TN, Bass J, Chang LW, et al. Persistent annular erythema of infancy. Pediatr Dermatol. 1993;10:46-48.

7. Kunz M, Hamm K, Bröcker EB, et al. Annular erythema in childhood — a new eosinophilic dermatosis [in German]. Hautarzt. 1998;49:131-134.

8. Stachowitz S, Abeck D, Schmidt T, et al. Persistent annular erythema of infancy associated with intestinal Candida colonization. Clin Exp Dermatol. 2000;25:404-405.

9. Wong L-C, Kakakios A, Rogers M. Congenital annular erythema persisting in a 15-year-old girl. Australas J Dermatol. 2002;43:55-61.

10. Patrizi A, Savoia F, Varotti E, et al. Neutrophilic figurate erythema of infancy. Pediatr Dermatol. 2008;25:255-260. doi:10.1111 /j.1525-1470.2008.00646.x

11. Saha A, Seth J, Mukherjee S, et al. Annular erythema of infancy: a diagnostic challenge. Indian J Paediatr Dermatol. 2014;15:147-149. doi:10.4103/2319-7250.143678

12. Pfingstler LF, Miller KP, Pride H. Recurring diffuse annular erythematous plaques in a newborn. JAMA Dermatol. 2014;150:565-566. doi:10.1001/jamadermatol.2013.8059

13. Del Puerto Troncoso C, Curi Tuma M, González Bombardiere S, et al. Neutrophilic figurate erythema of infancy associated with juvenile myelomonocytic leukemia. Actas Dermosifiliogr. 2015;106:431-433. doi:10.1016/j.ad.2014.09.013

14. Hamidi S, Prose NS, Selim MA. Neutrophilic figurate erythema of infancy: a diagnostic challenge [published online December 26, 2018]. J Cutan Pathol. 2019;46:216-220. doi:10.1111/cup.13394

15. Patel N, Goldbach $\mathrm{H}$, Hogeling $\mathrm{M}$. An annular eruption in a young child. JAMA Dermatol. 2018;154:1213-1214. doi:10.1001 /jamadermatol.2018.1174

16. Palit A, Inamadar AC. Annular, erythematous skin lesions in a neonate. Indian Dermatol Online J. 2012;3:45-47. doi:10.4103/2229-5178.93504

17. Keighley CL, Saunderson RB, Kok J, et al. Viral exanthems. Curr Opin Infect Dis. 2015;28:139-150. doi:10.1097/QCO.0000000000000145

18. Cronin DMP, George TI, Sundram UN. An updated approach to the diagnosis of myeloid leukemia cutis. Am J Clin Pathol. 2009;132:101-110. doi:10.1309/AJCP6GR8BDEXPKHR 


\section{APPENDIX}

\section{eTABLE. Summary of Annular Erythema of Infancy Cases}

\begin{tabular}{|c|c|c|c|c|c|}
\hline Reference (year) & Sex/age & $\begin{array}{l}\text { Clinical description } \\
\text { of rash }\end{array}$ & $\begin{array}{l}\text { Anatomic } \\
\text { location of rash }\end{array}$ & $\begin{array}{l}\text { Duration } \\
\text { of rash }\end{array}$ & Histopathology \\
\hline $\begin{array}{l}\text { Peterson and } \\
\text { Jarratt }^{2} \text { (1981) }\end{array}$ & $\mathrm{M} / 6 \mathrm{mo}$ & $\begin{array}{l}\text { Intermittent urticarial } \\
\text { eruption; some papules } \\
\text { appeared to have enlarged } \\
\text { centrifugally into } 2-3-\mathrm{cm} \\
\text { rings with urticarial borders }\end{array}$ & $\begin{array}{l}\text { Generalized, } \\
\text { sparing the } \\
\text { palms and soles }\end{array}$ & $8 \mathrm{mo}$ & $\begin{array}{l}\text { Moderate perivascular infiltrate } \\
\text { of lymphocytes and eosinophils }\end{array}$ \\
\hline $\begin{array}{l}\text { Toonstra and } \\
\text { de Wit }^{3} \text { (1984) }\end{array}$ & $\mathrm{F} / 8 \mathrm{mo}$ & $\begin{array}{l}\text { Large, irregularly shaped, } \\
\text { annular lesions with red, } \\
\text { raised, urticarial borders }\end{array}$ & $\begin{array}{l}\text { Face, back, } \\
\text { distal extremities }\end{array}$ & $11 \mathrm{mo}$ & $\begin{array}{l}\text { Moderately dense perivascular } \\
\text { infiltrates of lymphocytes, } \\
\text { histiocytes, and numerous } \\
\text { eosinophils present in the mid } \\
\text { and lower dermis }\end{array}$ \\
\hline $\begin{array}{l}\text { Hebert and Esterly }{ }^{4} \\
\text { (1986) }\end{array}$ & $\mathrm{F} / 7 \mathrm{mo}$ & $\begin{array}{l}\text { Recurrent asymptomatic } \\
\text { arcuate and annular skin } \\
\text { lesions beginning as "little } \\
\text { red dots" that enlarged } \\
\text { rapidly into a palpable } \\
\text { erythematous arc or ring }\end{array}$ & $\begin{array}{l}\text { Shoulder, back, } \\
\text { buttocks }\end{array}$ & & $\begin{array}{l}\text { Mild acanthosis and a dense } \\
\text { dermal perivascular infiltrate } \\
\text { composed of lymphocytes, } \\
\text { histiocytes, eosinophils, and a } \\
\text { few plasma cells }\end{array}$ \\
\hline Cox et al ${ }^{5}(1987)$ & $F / 2 y$ & $\begin{array}{l}\text { Asymptomatic annular } \\
\text { plaques with wide, raised, } \\
\text { firm, erythematous borders } \\
\text { without vesiculation or } \\
\text { formation of bullae }\end{array}$ & $\begin{array}{l}\text { Generalized, } \\
\text { face, upper } \\
\text { trunk, feet }\end{array}$ & 4 wk & $\begin{array}{l}\text { Edematous dermis } \\
\text { with an inflammatory } \\
\text { infiltrate of lymphocytes, } \\
\text { polymorphonuclear leukocytes, } \\
\text { and histiocytes around blood } \\
\text { vessels and to a lesser extent } \\
\text { around nerves and sweat glands } \\
\text { with no excess of eosinophils in } \\
\text { the inflammatory infiltrate }\end{array}$ \\
\hline Helm et al ${ }^{6}$ (1993) & $\mathrm{M} / 22 \mathrm{mo}$ & $\begin{array}{l}\text { Widespread erythematous } \\
\text { eruption with no }\end{array}$ & $\begin{array}{l}\text { Lower } \\
\text { extremities }\end{array}$ & $14 \mathrm{mo}$ & $\begin{array}{l}\text { Perivascular infiltrate with } \\
\text { eosinophils }\end{array}$ \\
\hline Kunz et $\mathrm{al}^{7}$ (1998) & $M / 4 y$ & $\begin{array}{l}\text { Nonitching erythematous } \\
\text { papules on the trunk that } \\
\text { evolved into annular } \\
\text { and gyrate erythemas } \\
\text { within weeks }\end{array}$ & Trunk & $\begin{array}{l}\text { Several } \\
\text { months }\end{array}$ & $\begin{array}{l}\text { Striking eosinophilic } \\
\text { inflammatory infiltrate } \\
\text { predominantly in perivascular } \\
\text { areas, without peripheral blood } \\
\text { eosinophilia }\end{array}$ \\
\hline $\begin{array}{l}\text { Stachowitz et al }{ }^{8} \\
\text { (2000) }\end{array}$ & $\mathrm{M} / 4.5 \mathrm{mo}$ & $\begin{array}{l}\text { Well-demarcated, slightly } \\
\text { itching, biocular erythema } \\
\text { with a raised border }\end{array}$ & $\begin{array}{l}\text { Periorbital } \\
\text { regions }\end{array}$ & $2.5 \mathrm{mo}$ & NA \\
\hline Wong et al ${ }^{9}$ (2002) & $F / 15 y$ & $\begin{array}{l}\text { Persisting extensive } \\
\text { annular erythematous } \\
\text { eruption since birth }\end{array}$ & Trunk & NA & $\begin{array}{l}\text { Heavy mixed inflammatory } \\
\text { infiltrate of lymphocytes, } \\
\text { neutrophils, histiocytes, and } \\
\text { eosinophils, both perivascularly } \\
\text { and extending diffusely } \\
\text { throughout the dermis }\end{array}$ \\
\hline
\end{tabular}


eTABLE. (continued)

\begin{tabular}{|c|c|c|c|c|c|}
\hline Reference (year) & Sex/age & $\begin{array}{l}\text { Clinical description } \\
\text { of rash }\end{array}$ & $\begin{array}{l}\text { Anatomic } \\
\text { location of rash }\end{array}$ & $\begin{array}{l}\text { Duration } \\
\text { of rash }\end{array}$ & Histopathology \\
\hline Patrizi et al ${ }^{10}$ (2008) & $\mathrm{M} / 21 \mathrm{mo}$ & $\begin{array}{l}\text { Annular erythematous } \\
\text { lesions with elevated } \\
\text { borders and central } \\
\text { resolution without scaling, } \\
\text { vesicles, or crusts }\end{array}$ & $\begin{array}{l}\text { Face, lower and } \\
\text { upper extremities }\end{array}$ & NA & $\begin{array}{l}\text { Diffuse interstitial and } \\
\text { perivascular infiltrate of } \\
\text { neutrophils and lymphocytes } \\
\text { with nuclear dust }\end{array}$ \\
\hline Saha et $\mathrm{al}^{11}$ (2014) & $M / 5 d$ & $\begin{array}{l}\text { Multiple brightly } \\
\text { erythematous, annular } \\
\text { plaques with palpable } \\
\text { expanding borders and no } \\
\text { detectable scaling } \\
\text { or atrophy }\end{array}$ & $\begin{array}{l}\text { Chest, back, } \\
\text { arms, thighs, } \\
\text { and face }\end{array}$ & NA & $\begin{array}{l}\text { Superficial and deep } \\
\text { perivascular lymphohistiocytic } \\
\text { inflammatory infiltrate }\end{array}$ \\
\hline $\begin{array}{l}\text { Pfingstler et al }{ }^{12} \\
\text { (2014) }\end{array}$ & $\mathrm{F} / 5 \mathrm{~d}$ & $\begin{array}{l}\text { Discrete, annular, } \\
\text { erythematous plaques } \\
\text { with raised borders and } \\
\text { central clearing }\end{array}$ & $\begin{array}{l}\text { Chest, arms, } \\
\text { and neck }\end{array}$ & $3-6 w k$ & $\begin{array}{l}\text { Diffuse inflammatory infiltrate } \\
\text { with a predominance of } \\
\text { eosinophils }\end{array}$ \\
\hline $\begin{array}{l}\text { Del Puerto } \\
\text { Troncoso et al }{ }^{13} \\
\text { (2015) }\end{array}$ & $F / 2 y$ & $\begin{array}{l}\text { Multiple annular and } \\
\text { polycyclic, erythematous } \\
\text { plaques with indurated } \\
\text { borders and petechiae } \\
\text { on the rims }\end{array}$ & $\begin{array}{l}\text { Upper chest, } \\
\text { abdomen, anc } \\
\text { upper back }\end{array}$ & NA & $\begin{array}{l}\text { Superficial and deep } \\
\text { perivascular and interstitial } \\
\text { mixed-cell dermatitis, composed } \\
\text { predominantly of neutrophils } \\
\text { with abundant nuclear dust }\end{array}$ \\
\hline Hamidi et $\mathrm{al}^{14}$ (2018) & $\mathrm{F} / 9 \mathrm{mo}$ & $\begin{array}{l}\text { Annular erythematous } \\
\text { lesions with raised borders } \\
\text { and central clearing }\end{array}$ & $\begin{array}{l}\text { Face, arms, } \\
\text { and legs }\end{array}$ & $6 \mathrm{mo}$ & $\begin{array}{l}\text { Superficial and deep } \\
\text { perivascular and interstitial } \\
\text { infiltrate composed of numerous } \\
\text { neutrophils and scattered } \\
\text { eosinophils with nuclear dust }\end{array}$ \\
\hline Patel et al ${ }^{15}$ (2018) & $\begin{array}{l}\text { Young } \\
\text { child }\end{array}$ & $\begin{array}{l}\text { Faint, nonscaling, annular, } \\
\text { serpiginous, erythematous } \\
\text { plaques with central } \\
\text { clearing and barely } \\
\text { elevated borders }\end{array}$ & $\begin{array}{l}\text { Lower legs, } \\
\text { abdomen, } \\
\text { and buttocks }\end{array}$ & $6 \mathrm{mo}$ & $\begin{array}{l}\text { Superficial and deep, } \\
\text { perivascular, and interstitial } \\
\text { inflammatory infiltrate consisting } \\
\text { of lymphocytes, histiocytes, } \\
\text { neutrophils, and eosinophils }\end{array}$ \\
\hline Current case & & $\begin{array}{l}\text { Annular erythematous } \\
\text { patches and plaques }\end{array}$ & $\begin{array}{l}\text { Back, arms, } \\
\text { and legs }\end{array}$ & $6 \mathrm{mo}$ & $\begin{array}{l}\text { Superficial to mid dermal, tight, } \\
\text { coat sleeve-like, perivascular, } \\
\text { lymphohistiocytic infiltrate } \\
\text { admixed with rare neutrophils in } \\
\text { eosinophils within the dermis }\end{array}$ \\
\hline
\end{tabular}

Abbreviations: $M$, male; $F$, female; NA, not available. 